\title{
“BUNDO KANDUANG” MINANGKABAU Vs. KEPEMIMPINAN
}

\author{
ERMI SOLA \\ ermisola18@gmail.com \\ Fakultas Tarbiyah dan Keguruan
}

\section{ABSTRAK}

Minangkabau merupakan salah satu etnis terbesar di Indonesia dengan sistem kekerabatan yang berbeda. Masyarakat Minangkabau memiliki adat yang unik dengan menganut sistem matrilineal. Adat istiadat Minangkabau mengatur tatanan masyarakatnya baik secara individu, kelompok maupun sosial. Penghulu adalah sebutan atau gelar yang diberikan kepada pemimpin adat dalam masyarakat Minangkabau. Penghulu merupakan orang yang dituakan, dipilih dan dipercayakan untuk memimpin masyarakat. Bundo kanduang merupakan seorang perempuan yang sudah menikah. Bundo kanduang merupakan pemimpin non formal bagi seluruh perempuan dan anak cucunya dalam suatu kaum. Semua keputusan berada di tangannya. Tanpa adanya izin dari bundo kanduang, semua rencana belum dapat dilaksanakan.

Kata kunci: Matrilinial, Bundo kanduang, Kepemimpinan

\section{ABSTRACT}

Minangkabau is one of the greatest ethnics in Indonesia with different kindship system. Minangkabau community has an unique "lineage" system. Minangkabau custom manages its community's (individual, groups, and social) life. "Penghulu" or headman is a title given to a leader-an old right person chosen to lead the community. Bundo Kanduang is a married woman-a mother. Bundo kanduang is a non formal leader for all women and their grandchildren in its clan. All decisions are in her hands. Without Bundo kanduang's permission, all plannings can be implemented.

\section{Key words: Lineage, Bundo Kanduang, Leadearship}

\section{PENDAHULUAN}

Minangkabau merupakan salah satu etnis terbesar di Indonesia dengan sistem kekerabatan yang berbeda. Masyarakat Minangkabau memiliki adat yang unik dengan menganut sistem matrilineal. Adat istiadat Minangkabau mengatur tatanan masyarakatnya baik secara individu, kelompok maupun sosial. Tatanan kehidupan yang telah diatur tersebut menjadi pegangan hidup masyarakat 
Minangkabau.. Navis (1982: 88-89) mengemukakan bahwa adat merupakan kebudayaan secara utuh yang dapat berubah. Namun ada adat yang tidak dapat berubah, seperti kata pepatah "kain dipakai usah, adaik dipakai baru” (kain dipakai usang, adat dipakai baru). Pepatah tersebut bermakna bahwa pakaian ketika dipakai terus, lama kelamaan akan usang. Tetapi ketika adat dipakai terus menerus akan senantiasa awet/langgeng.

Secara garis besar, adat Minangkabau terbagi ke dalam 2 kategori, yakni adat yang tetap, tidak berubah dan adat yang berubah. Ke 2 kategori tersebut diklasifikasikan ke dalam 4 bagian; 1) adat yang sebenar adat, 2) adat istiadat, 3) adat yang diadatkan, dan 4) adat yang teradat. Adat yang sebenar adat. Adat yang sebenar adat adalah adat yang asli, tidak berubah, tak lapuk oleh hujan tak lekang oleh panas. Kalaupun dipaksa mengubah/mengikisnya, maka ia "dicabuik indak mati, diasak indak layua" (dicabut tidak mati, dipindahkan tidak layu). Adat yang lazim berlaku sesuai pepatah ini adalah hukum alam yang merupakan falsafah hidup orang Minangkabau. Adat istiadat, yakni kebiasaan yang berlaku di tengah masyarakat setempat, seperti acara seremoni, atau tingkah laku dalam pargaulan yang jika dilakukan dianggap baik dan bila tidak dilakukan tidak apa-apa. Adat isitiadat ini diumpamakan dengan sayuran yang "gadang dek diambak, tinggi dek dianjuang" (besar karena dilambuk, tinggi karena dianjung). Artinya, adat akan tetap tumbuh karena dirawat dengan baik. Adat yang diadatkan, yaitu apa yang disebut sebagai undang-undang atau hukum yang berlaku, seperti "Undang-undang Luhak dan rantau, Undang-undang nan Duo Puluah". Pepatah/ mamangan terhadap adat ini "jikok dicabuik mati, jikok diasak layua" (jika dicabut mati, jika dipindahkan layu). Ibarat pohon yang hidup tumbuh berakar; pohon yang tumbuh apabila tidak ada tangan yang mengganggu. Adat yang teradat, yakni peraturan yaang lahir dari hasil mufakat atau konsensus masyarakat pemakainya, seperti pepatah "patah tumbuah hilang baganti" (patah tumbuh, hilang berganti). Ibarat pohon yang patah karena bencana, maka ia akan dapat tumbuh lagi pada bekas patahannya. Kala ia hilang, ia diganti pohon lain pada bekas tempatnya hilang karena pohon perlu ada untuk keberlangsungan hidup manusia Maknanya diperlukannya pemimpin untuk memimpin jalannya roda pemerintahan agar adat di Minangkabau tetap langgeng. 
Kepemimpinan secara prinsip merupakan upaya memengaruhi banyak orang melalui komunikasi untuk mencapai tujuan. Kepemimpinan juga merupakan suatu kegiatan dalam membimbing suatu kelompok sehingga tercapai tujuan bersama yang telah disepakati. Kepemimpinan juga bermakna sekumpulan/ serangkaian kemampuan dan sifat-sifat kepribadian individu--pemimpin, termasuk di dalamnya kewibawaan untuk dijadikan sebagai sarana dalam rangka meyakinkan individu/kelompok yang dipimpin agar mereka mau melaksanakan tugas-tugas yang dibebankan kepadanya dengan rela hati, bersemangat dan kegembiraan batin (Kompri, 2015: 307). Keberhasilan berbagai kelompok sangat bergantung pada kualitas pemimpin yang terdapat dalam kelompok masyarakat bersangkutan (Siagian, 1991: 2). "Penghulu" atau "Datuak" adalah sebutan atau gelar yang diberikan kepada pemimpin adat dalam masyarakat Minangkabau. Penghulu merupakan orang yang dituakan, dipilih dan dipercayakan untuk memimpin masyarakat dengan gelar "Datuak".

Perempuan dalam bahasa Minangkabau disebut padusi. Dalam adat Minangkabau, perempuan mendapat porsi dan posisi yang sangat istimewa karena segala keputusan berada di tangannya. Artinya, tanpa adanya izin dari perempuan, maka segala rencana belum dapat dilaksanakan. Perempuan Minangkabau yang sudah menikah disebut sebagai bundo kanduang (ibu kandung). Secara sederhana, bundo kanduang merupakan seorang pemimpin non formal bagi seluruh perempuan dan anak cucunya dalanm suatu kaum. Kepemimpinan tersebut tumbuh atas kemampuan dan kharismanya sendiri yang didukung dan diakui oleh anggota-anggota kaumnya (Diradjo, 2009: 346). Berdasarkan adat bersendi syarak, syarak bersendi kitabullah, peran bundo kanduang adalah 1) sebagai urang rumah (pemilik rumah); orang Minangkabau harus selalu memiliki rumah dan tanah kuburan milik keluarga. 2) sebagai induak bareh; ibu rumah tangga yang mengatur makanan dan minuman seluruh keluarga besar, yang miskin dibantu yang besar diajak bicara. 3) arif; azas utama bagi kepemimpina di tengah masyarakat. 


\section{PEMBAHASAN}

\section{A. KONSEP KEPEMIMPINAN MINANGKABAU}

"Penghulu" adalah sebutan atau gelar yang diberikan kepada pemimpin adat dalam masyarakat Minangkabau. Penghulu merupakan orang yang dituakan, dipilih dan dipercayakan untuk memimpin masyarakat. Dahulunya penghulu digunakan dalam struktur pemerintahan di wilayah Minangkabau, di samping sebagai pemangku adat dengan gelar "Datuak” (Suryani, 2014: 208). Singkatnya, penghulu adalah orang yang memimpin, memerintah, dan membawahi masyarakat, termasuk anak dan kemenakan. Jamrah (2019: 8-10) mengemukakan bahwa dalam proses pemilihan penghulu/"datuak", seseorang harus memiliki kriteria, yakni:

1) Memenuhi 4 sifat Nabi: Sidik, Tabligh, Amanah, dan Fathanah,

a. Siddiq, yaitu benar dan tidak merubah yang benar kepada yang salah.,

b. Tablig, yaitu seorang pemimpin menyampaikan hukum syarak (agama) kepada seluruh kaum kerabatnya,

c. Amanah, yaitu memegang teguh kepercayaan yang telah diterima untuk dilaksanakan sepenuhnya pada kaum kerabatnya,

d. Fathanah, yaitu cerdik dan kuat dalam bekerja sehingga memberikan manfaat yang terbaik bagi masyarakat yang dipimpinnya. Di samping itu, dapat menyelesaikan benang kusut atau rmasalah yang timbul di tengah-tengah masyarakat.

2) Loyalitas yang tinggi terhadap kaum, suku, anak kemenakan dan "nagari",

3) Berilmu pengetahuan tentang adat dan agama dan lain lain,

4) Adil dalam memimpin anak kemenakan dan keluarga,

5) Berani dalam menegakkan kebenaran dan mencegah kebathilan,

6) Taat menjalankan ajaran agama dan adat,

7) Tidak cacat moral di mata masyarakat dalam nagari.

Martabat seorang pemimpin/datuak antara lain terletak pada 1) berakal dan kuat pendirian, 2) berilmu, berpaham, berma'rifat ujud yakin, tawakal pada Allah, 3) kaya dan miskin pada hati dan kebenaran, 4) murah dan mahal pada laku dan perangai yang berpatutan., 5) hemat dan cermat, 
mengenai awal dan akhir, 6) ingat dan ahli pada adat. Dengan martabat yang melekat pada diri seorang penghulu/datuak, sangat wajar jika dalam masyarakat Minangkabau seorang penghulu/datuak sangat disegani dan dihormati, terutama oleh kaumnya.

Pemimpin menurut adat Minangkabau hanya ditinggikan sarantiang dan didahulukan salangkah sehingga masyarakat masih bisa menjangkaunya dengan tangan dan masih dapat mengingatkannya. Pemimpin itu bagaikan "tinggi sarantiang jombo-jomboan sarangguik, runtuah badaram, didahulukan salangkah bajarak tungkai-tungkaian sahambua lompeklah tibo sadatiak wakatu nampak satitiak salah basuo baitu ukua jo jangko di dalam alam Minangkabau".

Itulah sebabnya pemimpin disebut dengan "Bak kayu gadang ditangah koto ureknyo tampek baselo batangnyo tampek basanda dahannyo tampek bagantuang daun rimbunnyo tampek bataduah, tampek bahimpun hambo rakyat, pai tampek batanyo pulang tampek babarito, sasek nan kamanyapo tadorong nan kamanyintak, tibo dikusuik kamanyalasai tibo dikaruah mampajaniah, mahukum adia bakato bana".

Beberapa prinsip-prinsip kepemimpinan seorang penghulu/datuak yang dapat membentuk masyarakat yang kuat dan berkarakter adalah:

1. Kamanakan barajo ka mamak, mamak barajo ka panghulu, panghulu barajo ka mufakat, mufakat barajo ka nan bana; menegakkan kebenaran sesuai peraturan,

2. Hilang nan ka mancari, anyuik ka maminteh, luluih nan ka manyalami; perhatian yang besar pada masyarakat,

3. Indak lamak karano santan, indak kuniang karano kunyik; berpendirian dan berprinsip,

4. Kato putuih, biang tabuak; bijaksana dalam mengambil keputusan,

5. Tinggi tampak jauah, gadang tampak ampia; dapat menempatkan diri,

6. Bahari abih babadan litak, rantau jauah diulangi, rantau dakek dikana; senang dekat dengan masyarakat,

7. Bakato baiyo, bajalan bamolah, duduak surang basampik-sampik, duduak basamo balapang-lapang; mengutamakan musyawarah, 
8. Kapai tampek batanyo, pulang tampek babarito; menjadi tumpuan masyarakat,

9. Manimbang samo barek, maukua samo panjang, mamanggang samo merah; bertindak adil,

10. Tibo diparuik indak dikampihkan, tibo di dado indak dibusuangkan, tibo dimato indak dipiciangkan; memperlakukan adil/ sama semua orang,

11. Baalam laweh bapadang lapang; penyabar dan bisa menerima kritik.

12. Didahulukan salangkah, ditinggikan sarantiang, dianjuang tinggi, diamba gadang; dekat dengan masyarakat, jaraknya hanya selangkah,

13. Singkek mauleh, lamah manahua, kurang manukuak, senteang mambilai; dapat memberi bantuan,

14. Kusuik ka manyalasai, karuah mampajaniah; dapat menyelesaikan masalah,

15. Pusek jalo pumpunan ikan, bukik timbunan kabuik, taluak timbunan kapa; menjadi tempat berpegang bagi masyarakat.

\section{B. BUNDO KANDUANG MINANGKABAU}

Perempuan dalam bahasa Minangkabau disebut padusi. Dalam adat Minangkabau, perempuan mendapat porsi dan posisi yang sangat istimewa karena segala keputusan berada di tangannya. Artinya, tanpa adanya izin dari perempuan, maka segala rencana belum dapat dilaksanakan. Kedudukan tertinggi perempuan Minangkabau adalah bundo kanduang, yakni sebutan bagi perempuan Minangkabau yang sudah menikah. Adanya bundo kanduang dalam suatu kaum karena setiap kaum memerlukan seorang pemimpin perempuan yang dapat memimpin seluruh perempuan beserta anak cucu yang ada dalam kaumnya. Kepemimpinan tersebut tumbuh atas kemampuan dan kharismanya sendiri yang didukung dan diakui oleh anggota-anggota kaumnya (Diradjo, 2009: 346). Berdasarkan adat bersendi syarak, syarak bersendi kitabullah, peran bundo kanduang adalah 1) sebagai urang rumah (pemilik rumah); orang Minangkabau harus selalu memiliki rumah dan tanah kuburan milik keluarga. 2) sebagai induak bareh; ibu rumah tangga yang mengatur makanan dan minuman seluruh keluarga besar, yang miskin dibantu yang besar diajak bicara. 3) arif; azas utama bagi kepemimpina di tengah masyarakat. Untuk itu, setiap 
perempuan Minangkabau harus terdidik dan berpendidikan, sehingga tau alua jo patuik, tau rantiang nan kamancucuak, alun takilek lah takalam. Dt. Diradjo (2009), 272-282, 374) mengemukakan bahwa dalam titah adat alam Minangkabau, karakter dan tindakan padusi atau perempuan dapat diklasifikasikan kepada tiga sebutan, yakni: 1) Padusi Simarewan. Padusi Simarewan "bapaham sarupo gatah cayia, iko elok itu katuju, bak cando pimpiang di lereang, baparangai sarupo pucuak aru, ka mano angin inyo ka kian, alun dijujai inyo lah galak, alun diimbau inyo lah datang..." Artinya, Padusi Simarewan memiliki karakter sebagai seseorang yang tidak mempunyai pendirian, mudah tergoda dan dirayu, banyak ketawa daripada bicara, kurang sopan dan tidak punya rasa malu. Singkat kata, padusi Simarewan berprilakunya jelek dan tidak menampakkan diri sebagai perempuan Minangkabau. 2) Padusi Mambang Tali Awan. Padusi Mambang Tali Awan "kalau mangecek samo gadang, atau barundiang di nan rami, sagalo labiah dari urang, tasambia juo bapk si buyuang, basabuik juo bapak si upiak, nan sagalo labiah dari urang, baiak tantang pambalinyo, atau tantang kasiah sayangnyo, siang jo malam jarang di rumah, naiak rumah turun rumah. Artinya, Padusi Mambang Tali Awan memiliki karakter yang tidak lebih baik dari padusi Simarewan. Padusi Mambang Tali Awan ketika dalam berbicara dan berunding selalu menunjukkam bahwa dia lebih hebat dari yang lain termasuk suami, anak, menantu, saudara maupun kerabat. Selain itu, padusi Mambang Tali Awan juga suka bertandang ke rumah orang, bergunjing, suka menyebut aib orang, suka duduk dipinggir jalan, berlagak mampu tapi sebaliknya, tidak bisa memasak, kurang rasa malu dan sopan serta suka membuat keonaran di tengah masyarakat. 3) Parampuan atau perempuan. Parampuan "mano nan disabuik parampuan, mamakai taratik sarato sopan, nan mamakai baso jo basi, tau diereng saroto gendeng, mamakai raso jo pareso, manaruah malu sarato sopan, manjauahi sumbang sarato salah, muluik manih baso katuju, kato baiak kucindan murah..." yakni perempuan yang mempunyai karakter terpuji, baik budi pekerti dan tingkah laku maupun kecakapan, kemampuan dan ilmu pengetahuannya. Parampuan atau perempuan adalah limpapeh rumah nan gadang. 
Dalam kenyataan, ketiga klasifikasi perempuan tersebut secara umum hanya terdapat pada perempuan Minangkabau yang masih gadis. Setelah menikah, menjadi ibu dan tinggal di rumah gadang, ia akan berada di bawah pengaruh Mamak Tungganai, dan berperan sebagai Bundo Kanduang dan kaum saparuik-nya. Jika dilihat lebih jauh, perempuan Minangkabau ketika masih gadis, tidak pernah merdeka atau memiliki kebebasan dalam menentukan pilihan. Perempuan Minangkabau baru memperoleh kemerdekaan dalam menentukan pilihan dan pendapatnya bisa menjadi pertimbangan setelah perempuan Minangkabau mencapai kedudukan sebagai bundo kanduang. Artinya, selama belum mencapai kedudukan sebagai bundo kanduang, perempuan Minangkabau akan terus hidup di bawah pengaruh "mamak" atau paman. Dari sisi gender, perempuan Minangkabau mendapat posisi yang istimewa dan spesial. Namun, keistimewaan itu tidak didapat sejak lahir yang sudah bebas dengan segala pilihan. Perempuan Minangkabau masih berada di bawah bayang-bayang patriaki,yang dalam hal ini mamak.

Pada prinsipnya banyak karakter baik yang dimiliki parampuan Minangkabau, seperti sabar menurut titah dan nasehat suaminya, orangtuanya, dan ninik mamak serta sanak saudaranya. Lebih jauh, parampuan Minangkabau wajib memberi teladan yang baik bagi anak-anaknya. Hal ini dikarenakan parampuan Minangkabau memiliki tiga martabat yang wajib ia miliki dan terapkan dalam kehidupan bermasyarakat, yaitu: memelihara rasa malu, teguh akan janjinya dan berilmu, baik kepada Allah maupun kepada makhluk. Jika parampuan tidak punya rasa malu, tidak sopan-santun, maka perempuan itu ibarat gulai yang tak diberi garam karena rasa malu kulitnya iman, teguh janji, dan kuat akalnya, baik lahir maupun batin. Apabila seorang perempuan tidak tetap akalnya, ibarat perahu yang tak berkemudi; akibatnya terombang-ambing di laut lepas. Sifat perempuan bila menjadi bundo kanduang tersebut dinyatakan dalam kato pusako (kata pusaka) "dihias jo budi baiak, malu sopan tinggi sakali, Baso jo basi bapakaian, nan gadang basa batuah, kok hiduik tampek banzar, kok mati tampek baniat. Tiang kokoh budi nan baiak, pasak kunci malu jo sopan, hiasan dunia jo akhirat, awuih tampek mintak aia, lapa tampek minta nasi" (Zulkarnaini, 1994 dalam Nurman: Jurnal 
Al-Aqidah, Volume 11, Edisi 1, Juni 2019). Kata pusaka tersebut mengandung makna yang dalam, yakni kehadiran perempuan sebagai bundo kanduang merupakan teladan bagi rumah tangga, kaumnya, dan masyarakatnya. Sosok bundo kanduang digambarkan sebagai ibu yang berwibawa, arif bijaksana, suri teladan, memakai raso (rasa) dan pareso (periksa), serta tutur katanya sopan (Nurman: Jurnal Al-Aqidah, Volume 11, Edisi 1, Juni 2019).

Singkat kata, perempuan dan bundo kanduang berbeda secara maknawi. Kata perempuan bermakna umum dan acuannya luas, sedangkan frasa "bundo kanduang" mengacu kepada sosok perempuan yang punya sifat dan kepribadian yang (1) memahami adat dan sopan santun,(2) mengutamakan budi pekerti, (3) memelihara harga diri, (4) mengerti agama, (5) memahami aturan agama, (6) memelihara dirinya dan masyarakatnya dari dosa. Dalam adat Minangkabau perempuan diklasifikasikan menjadi tiga bagian, yakni (1) parampuan, (2) simarewan, dan (3) mambang tali awan. Parampuan, merujuk kepada perempuan yang berpekerti baik, tawakal kepada Allah, sopan dan hormat pada sesama. Karakternya terlihat dalam kato pusako budi tapakai taratik dengan sopan, memakai baso-basi di ereng jo gendeang, tahu kepada sumbang salah, takut kepada Allah dan Rasul, muluik manih baso katuju, pandai bagaua samo gadang, hormat pado ibu jo bapa, baitupun jo urang tuo. Simarewan, merujuk kepada perempuan yang tidak mempunyai pendirian, tidak berbudi pekerti baik. Kepribadiannya terlihat dalam kato pusako paham sebagai gatah caia, iko elok etan katuju, bak cando pimpiang di lereng, bagai baliang-baliang di puncak bukik, ka mano angin inyo kakian, bia balaki umpamo tidak, itulah bathin kutuak Allah, isi narako tujuan lampih. Mambang tali awan, adalah perempuan yang sombong, tidak punya rasa hormat, tenggang rasa, selalu ingin kedudukannya. Kepribadian perempuan seperti ini diungkapkan dalam kata pusaka parampuan tinggi ati, kalau mangecek samo gadang, barundiang kok nan rami, angan-angan indak ado ka nan lain, tasambia juo laki awak, dibincang-bincang bapak si upiak, atau tasabuik bapak si buyuang, sagalo labiah dari urang, baiklah tantang balanjonyo, baiak kasiah ka suami, di rumah jarang baranjak-ranjak, dilagakkan mulia tinggi pangkek, sulit nan lain 
manyamoi, walau suami jatuah hino, urang disangko tak baiduang, puji manjulang langik juo.

\section{BUNDO KANDUANG MINANGKABAU Vs. KEPEMIMPINAN}

Sistem kekerabatan matrilineal Minangkabau terkenal karena memiliki populasi terbesar di dunia yang menganut sistem matrilineal. Sistem kekerabatan matrilineal menempatkan perempuan dalam posisi yang tinggi dan penentu garis keturunan, Seorang anak lelaki atau perempuan adalah anggota kelompok kerabat ibunya. Pola perkawinan bersifat eksogami. Kedua belah pihak atau salah satu pihak dari yang menikah tidak lebur ke dalam kaum kerabat pasangannya karena setiap orang adalah warga kaum dan suku mereka masing-masing yang tidak dapat dialihkan. Artinya, meskipun sudah menikah, suami/istri tetap sebagai anggota kaumnya masing-masing (Navis, 1992: 193-194).

Menurut istilah antropologi terdapat perbedaan antara matriakhat (pemegang kekuasaan) dan matrilineal (penerus keturunan). Sanday (1998) mengemukakan bahwa masyarakat Minangkabau tidak hanya menganut sistem matrilineal, tapi juga patrilinial. Perempuan Minangkabau memiliki kekuasaan sekaligus sebagai penerus garis keturunan. Sistem garis keturunan matrilineal menempatkan perempuan sebagai inidividu yang berkuasa penuh atas dirinya. Di sisi lain, pola hidup komunal menjadikan perempuan Minangkabau tidak bergantung sepenuhnya pada laki-laki atau suaminya. Dalam hubungan sosial perempuan diibaratkan dengan tiang utama rumah gadang. Sebagai tiang yang paling utama karena perempuan sebagai pusat, asal usul, dan dasar, tidak hanya tentang hidup dan kehidupan, tetapi juga tatanan ekonomi, dan sosial.

Dalam konsep adat, parampuan bundo kanduang dihormati dan disegani. Mereka mempunyai status yang tinggi. Bundo kanduang (Bundo Kandung) merupakan Limpapeh rumah nan gadang (rama-rama penghias rumah gadang), sumarak di dalam kampuang (semarak di dalam kampung); hiasan dalam nagari (hiasan dalam nagari); kok iduik tampek banasa (waktu 
hidup tempat bernazar); kok mati tampek baniat (kalau meninggal tempat berniat); kaunduang-unduang ka Madinah (sebagai pelindung ke Madinah); ka payuang panji kasarugo (sebagai payung panji untuk ke surga); cahayo rumah selendang dunie (cahaya rumah selendang dunia) (Amir, 2007:52). Bundo kanduang merupakan aktor intelektual di dalam menyelesaikan berbagai persoalan yang terjadi dalam kaumnya. Namun, suara perempuan Minangkabau baru didengar ketika ia sudah menjadi istri atau ibu dan ketika sudah menjadi bundo kanduang. Jika belum menikah, perempuan Minangkabau masih berada pada aturan dan pengawasan mamak/paman (Syahrizal: 2005).

Seperti sebuah negara selain Pemerintahan Nagari yang dipimpin oleh Wali Nagari, di dalam sebuah nagari juga terdapat lembaga-lembaga lain yang menjadi mitra pemerintahan nagari untuk mengurus kepentingan masyarakat, membangun, dan memberdayakan masyarakat. Lembaga-lembaga yang ada di nagari selain pemerintahan nagari contohnya adalah Badan Perwakilan Anak Nagari (BPRN), Kerapatan Adat Nagari (KAN), Majlis Musyawarah Adat dan Syarak Nagari (MAMAS), Majlis Ulama Nagari (MUN), Bundo Kanduang (BK) dan lain-lain. Lembaga-lembaga yang ada di Nagari diatur dalam Peraturan Daerah Propinsi. Susunan organisasi dan tata tertibnya diatur lebih luas dalam Peraturan Daerah Kabupaten. Lembaga-lembaga yang ada di nagari ini tidak harus sesuai dengan apa yang terdapat dalam Perda. Masyarakat nagari bisa membentuk lembaga-lembaga sesuai dengan kebutuhan. Dalam Peraturan Daerah Kabupaten Agam No. 31 tahun 2001 Pasal 107 disebutkan bahwa dalam upaya memberdayakan masyarakat di nagari dapat dibentuk lembaga-lembaga kemasyarakatan lainnya.Salah satu lembaga di Nagari yang terdapat dalam Perda adalah lembaga Bundo Kanduang yang seluruh angotanya adalah perempuan. Pembentukan lembaga Bundo Kanduang adalah salah satu upaya struktural untuk meningkatkan peran perempuan dalam kehidupan sosial budaya .Pembentukan lembaga Bundo Kanduang dianggap tokoh-tokoh masyarakat sebagai usaha untuk meningkatkan peran perempuan dalam pembangunan Nagari yang kedudukannya sama dengan lembaga-lembaga lain di nagari. Dalam hal ini, tugas utama bundo kanduang 
dalam tatanan sosial kelembagaannya adalah memelihara kelestarian adat, menjaga harta pusaka, sampai mengawasi perilaku remaja atau generasi muda yang sering terjerumus kepada gaya hidup yang tidak sesuai dengan nilai-nilai adat dan agama, semisal cara berpakaian dan bersikap remaja perempuan yang banyak "sumbang" menurut adat; tata tertib meletakkan jamuan dalam pesta di mana lutut harus ditekuk ke lantai tidak boleh jongkok; yang terjadi justru sebaliknya.

Pada dasarnya, perempuan bisa duduk di lembaga-lembaga lain selain Bundo Kanduang dan BPRN kecuali KAN karena KAN adalah tempat berkumpulnya para ninik mamak (laki-laki kepala sub klen matrilineal). Namun, masih sangat kurang keterlibatan perempuan dalam kelembagaan nagari. Kekurangterlibatan perempuan bundo kanduang sebagai pemimpin dalam kehidupan organisasi kemasyarakatan di nagari lebih dikarenakan pandangan mereka bahwa perempuan memiliki banyak keterbatasan, terutama berkaitan dengan persoalan reproduksi seperti hamil, melahirkan, dan menyusui. Di samping itu, alasan keterbatasan fisik dalam menghadapi berbagai persoalan pelik seperti masyarakat yang berkelahi, atau kesulitan menghadiri rapat-rapat yang diadakan pada malam hari.

\section{PENUTUP}

Adat Minangkabau secara khusus membentuk pribadi individu yang berbudi luhur, berbudaya, dan beradab. Sifat-sifat ideal itu adalah a) hiduik baraka, baukua jo bajangko; masyarakat Minangkabau harus mempunyai "rencana yang jelas dan perkiraan yang tepat"; b) baso-basi malu jo sopan; adat Minangkabau mengutamakan sopan santun dalam pergaulan; c) tenggang raso; artinya di dalam pergaulan yang baik harus menjaga perasaan orang lain dan d) setia; teguh hati, merasa senasib dan menyatu dalam lingkungan kekerabatan. Posisi perempuan dalam adat Minangkabau sangat menentukan termasuk dalam mengambil keputusan. Perempuan sebagai bundo kanduang menjadi sumber utama dan penentu dalam mengambil keputusan. Dalam musyawarah adat materi keputusan dan segala yang akan diputuskan terlebih dahulu 
dikonsultasikan dan diminta persetujuan oleh mamak ke bundo kanduang. Hasil keputusan yang diambil dalam musyawarah disampaikan kembali pada bundo kanduang, karena implementasi keputusan dikoordinir bersama dengan bundo kanduang.

Namun, dewasa ini kekurangterlibatan perempuan bundo kanduang sebagai pemimpin dalam kehidupan kelembagaan organisasi kemasyarakatan di nagari lebih dikarenakan pandangan mereka bahwa perempuan memiliki banyak keterbatasan, terutama berkaitan dengan persoalan reproduksi seperti hamil, melahirkan, dan menyusui. Di samping itu, alasan keterbatasan fisik dalam menghadapi berbagai persoalan pelik seperti masyarakat yang berkelahi, atau kesulitan menghadiri rapat-rapat yang diadakan pada malam hari.

\section{RUJUKAN}

Afrizal. 2002. Rekonstruksi Nagari dan Gerakan Perempuan, Jurnal Antropologi, Tahun IV No. 6.

Amir. 2007. Adat Minangkabau: Pola Tujuan Hidup Orang Minang. Jakarta: PT Mutiara Sumber Widya,

Diradjo, Ibrahim Dt. Sanggoeno, 2009. Tambo Alam Minangkabau: Tatanan Adat Warisan Nenek Moyang Orang Minang. Bukittinggi: Kristal Multimedia

https://www/sumbarprov.go.id 2019. Jamrah, Alfian. Karakter kepemimpinan Menurut Kearifan Lokal Minangkabau

https://bunghatta.ac.id/artikel-107-peran-dan-kedudukan-perempuan-dalam-keb udayaanminangkabau.html Nurman, Silmi Novita. Kedudukan Perempuan Minangkabau dalam Perspektif Gender. Jurnal Al-Aqidah, Volume 11, Edisi 1, Juni 2019

Kompri, 2015. Manajemen Pendidikan 1. Bandung: Alfabeta

Navis. A. A. 1982. Alam Terkembang Jadi Guru: Adat dan Kebudayaan Minangkabau: Jakarta, Grafiti Pers.

ojs.badanbahasa.kemdikbud.go.id. Suryani. 2014. Konsep Kepemimpinan dalam Tambo Minangkabau. 
Penghulu, Idrus Hakimy Dt. Rajo Penghulu. 2004. Rangkaian Mustika Adat basandi Syarak di Minangkaba. Bandung: Remaja Rosda Karya

Penghulu, Idrus Hakimi Dt.Rajo. 1991. Pegangan Penghulu, Bundo Kanduang, dan Pidato Alua Pasambahan Adat Minangkabau. Bandung: PT. Remadja Rosdakarya.

Sanday, Peggy Reeves, 1998. "Matriarchy as a Sociocultural Form", Paper

Siagian, Sondang P. 1991. Teori dan Praktek Kepemimpinan. Jakarta: Rineka Cipta

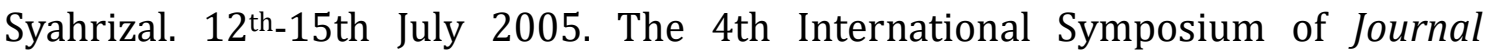
Antrophology Indonesia: Jakarta. 